\title{
PENERIMAAN, TINGKAT STRES, DAN STRATEGI KOPING IBU TERHADAP PROGRAM KONVERSI MINYAK TANAH KE LPG DI KABUPATEN BOGOR
}

\author{
Acceptance, Level of Stress, and Mother's Coping Strategy Regarding of Kerosene \\ Convertion Program to LPG in Bogor Regency
}

\author{
MELLY LATIFAH ${ }^{1^{*}}$, ANNE MARIA JUANDA $^{2}$ \\ ${ }^{1}$ Staf Pengajar Departemen IImu Keluarga dan Konsumen, Fakultas Ekologi Manusia, \\ Institut Pertanian Bogor, Jalan Lingkar Kampus IPB Dramaga, Bogor 16680 \\ ${ }^{2}$ Departemen IImu Keluarga dan Konsumen, Fakultas Ekologi Manusia, Institut \\ Pertanian Bogor, Kampus Dramaga, Bogor 16680
}

\begin{abstract}
The increasing number of Indonesian population over years $(2,6$ million per years) is causing the increasing demand of energy that cannot be avoided. Energy reserve is running low in Indonesia. Energy crisis triggers some problems that need new policy, especially in public policy. One of the government solutions for the overcome kerosene crisis is a convertion program from kerosene to LPG. This program is to decrease dependency of society toward kerosene. The main objective of this research was to analyze the mothers' responses to the program in Bogor Regency. The method of this research was cross sectional study with 80 samples. Pearson's Correlation and Linear Regression were used for data analysis. Research finding showed that those who used LPG had high acceptance levels. The higher of LPG use leads to the higher level of stress. There was a negative correlation between income per capita, family size with the acceptance levels. Incomes per capita and the acceptance levela influenced the samples' coping strategy.
\end{abstract}

Key words : acceptance, convertion, coping strategy, energy, kerosene, level of stress, LPG

\section{PENDAHULUAN}

Krisis ekonomi yang melanda Indonesia sejak pertengahan tahun 1997 berdampak pada penurunan tingkat pendapatan penduduk dan tingkat kesejahteraan penduduk. Terjadinya krisis ekonomi di Indonesia juga menimbulkan masalah lain, yaitu kenaikan harga bahan bakar minyak yang memicu kontroversi dari berbagai pihak (Hasyim 2005). Bahan bakar minyak (BBM) merupakan salah satu jenis energi yang banyak digunakan di Indonesia. Cadangan BBM di Indonesia semakin menipis sehingga untuk memenuhi kebutuhan masyarakat, pemerintah harus mengimpor BBM. Peningkatan harga BBM dunia berakibat pada pengurangan cadangan devisa negara dan meningkatnya biaya subsidi minyak, dan pada gilirannya dapat membebani APBN dari tahun ke tahun.

Untuk mengatasi kelangkaan BBM dan melonjaknya harga BBM, maka sejak tahun 2006 pemerintah telah mengambil kebijakan untuk melakukan konversi penggunaan bahan bakar dari minyak tanah ke gas dalam bentuk Liquefied Petroleum Gas (LPG), khususnya bagi masyarakat menengah ke bawah. Dalam hal ini, pemerintah berencana mengkonversi penggunaan sekitar 10 juta kilo liter minyak tanah ke 5,71 juta ton LPG hingga tahun 2010 yang berasal dari pengurangan subsidi minyak tanah yang dialihkan ke LPG. Menurut hitungan pemerintah, bila kebijakan tersebut dapat berjalan dengan baik, maka dalam empat tahun pemerintah dapat menghemat subsidi sebesar 30 triliun, meskipun pada awalnya membutuhkan biaya investasi sekitar 15 triliun (Anonim 2008).

Program pemerintah, terlebih yang berhubungan langsung dengan hajat hidup masyakarat, tidak begitu saja dapat diterima oleh seluruh masyakarat. Salah satunya 
dibuktikan oleh hasil penelitian mengenai program konversi minyak tanah ke LPG di wilayah Bekasi yang menunjukkan bahwa terdapat beberapa sikap negatif warga terhadap LPG, yakni sikap terhadap keamanan dan kenyamanan dalam menggunakan LPG (Nurmayanti 2009). Namun demikian, penelitian tersebut belum mencakup aspek psikologis masyarakat penerima program konversi tersebut. Oleh karena itu, penerimaan masyarakat miskin terhadap program pemerintah tersebut perlu dikaji lebih lanjut. Hal ini mengingat tingginya penerimaan terhadap program konversi minyak tanah ke LPG merupakan salah satu faktor penting yang mencerminkan keberhasilan program ini. Sementara itu, LPG dianggap sebagai teknologi baru bagi masyarakat miskin, sehingga program konversi minyak tanah ke LPG ini membutuhkan kemampuan adaptasi. Ketidakmampuan masyarakat untuk beradaptasi dengan teknologi yang baru ini bisa menjadi sumber stres tersendiri bagi sejumlah masyarakat miskin di Indonesia. Hal ini mengingat pendapat Melson (1980) yang menyatakan bahwa perubahan lingkungan yang terjadi tiba-tiba dapat menimbulkan stres, terutama pada kelompok ibu yang sehari-hari berhubungan dengan area domestik, khususnya dapur. Dalam program konversi minyak tanah ke LPG ini tentu saja diperlukan kemampuan strategi koping ibu, yaitu strategi yang dilakukan dalam upaya penyesuaian terhadap program baru tersebut untuk mengurangi dampak stres.

Berdasarkan paparan di atas, maka sangat penting untuk melakukan penelitian lebih mendalam tentang dampak sosial program konversi minyak tanah ke LPG, khususnya untuk mengetahui bagaimana penerimaan dan tingkat stres ibu terhadap program tersebut. Selain itu, perlu juga diteliti strategi koping yang dilakukan ibu terhadap program konversi minyak tanah ke LPG untuk mengetahui bagaimana tingkah laku penyesuaian yang dilakukan oleh ibu dalam upaya mengurangi atau menghilangkan stres (Sarwono 1992).

Tujuan umum dari penelitian ini adalah untuk menganalisis penerimaan, tingkat stres, dan strategi koping masyarakat terhadap program konversi minyak tanah ke LPG. Sedangkan tujuan khusus penelitian ini adalah: (1) mengidentifikasi karakteristik ibu dan keluarga penerima program konversi minyak tanah ke LPG; (2) mengidentifikasi penerimaan, tingkat stres, dan strategi koping ibu terhadap program konversi minyak tanah ke LPG; (3) menganalisis hubungan antara karakteristik ibu dan keluarga dengan penerimaan contoh terhadap program konversi minyak tanah ke LPG; (4) menganalisis hubungan antara penerimaan ibu terhadap program konversi minyak tanah ke LPG dengan tingkat stres contoh; (5) menganalisis hubungan antara tingkat stres dengan strategi koping ibu; dan (6) menganalisis faktor-faktor yang berpengaruh terhadap strategi koping ibu.

Hasil penelitian ini diharapkan dapat memberikan informasi tentang penerimaan, tingkat stres, dan strategi koping masyarakat terhadap program konversi minyak tanah ke LPG. Dengan demikian, dapat dijadikan bahan pertimbangan dalam membuat kebijakan-kebijakan pemerintah yang berhubungan dengan bahan bakar serta peningkatan taraf hidup dan kesejahteraan masyarakat yang lebih baik.

\section{METODE}

\section{Desain, Lokasi, dan Waktu}

Desain penelitian adalah cross sectional study. Penelitian ini dilakukan di Kabupaten Bogor. Waktu penelitian berlangsung mulai April sampai Juni 2009.

\section{Cara Pengambilan Contoh}

Kerangka contoh pada penelitian ini adalah penerima program konversi minyak tanah ke LPG, yaitu ibu rumah tangga yang berdomisili di Desa Suka Makmur dan Suka Harja (Kecamatan Ciomas), Desa Kemang dan Tegal (Kecamatan Kemang) yang dipilih secara acak sederhana. Contoh penelitian ditentukan dengan metode acak sederhana dari kerangka sampling. Kriteria contoh adalah ibu rumah tangga penerima program konversi minyak tanah ke LPG dan tinggal di Kabupaten Bogor.

\section{Pengolahan dan Analisis Data}

Data yang telah terkumpul diolah dan dianalisis dengan menggunakan statistik deskriptif dan inferensial untuk menganalisis penerimaan, tingkat stres, dan strategi koping contoh terhadap program konversi minyak tanah ke LPG. Data primer pada penelitian ini terdiri karakteristik contoh (umur, pendidikan, pekerjaan), karakteristik keluarga (umur, pendidikan dan pekerjaan suami, besar keluarga, pendapatan/ kapita/bulan), penerimaan contoh terhadap program konversi minyak tanah ke LPG, 
tingkat stres, dan strategi koping contoh.

Penerimaan contoh diukur dengan menggunakan instrumen Engel et al. (1994) yang telah dimodifikasi. Penerimaan terdiri dari dua jenis respon, yaitu respon kognitif dan afektif.

Tingkat stres diukur dengan melihat gejala-gejala yang dialami, baik gejala fisik maupun emosional. Gejala-gejala ini merupakan modifikasi dari McCubbin dan Thompson (1987).

Strategi koping dilihat dari perilaku yang diterapkan untuk mengatasi stres program konversi minyak tanah ke gas (LPG) yang digambarkan melalui pernyataan-pernyataan. Instrumen ini merupakan modifikasi dari FCOPES (Family Crisis Oriented Personal Scales) oleh McCubbin, Olson, dan Larsen (1981) dalam McCubbin dan Thompson (1987).

1. Uji Korelasi Pearson digunakan untuk menganalisis hubungan antara variabelvariabel:

a. Karakteristik contoh dan keluarga dengan penerimaan contoh terhadap program konversi minyak tanah ke LPG.

b. Penerimaan contoh terhadap program konversi minyak tanah ke LPG dengan tingkat stres contoh.

c. Tingkat stres contoh dengan strategi koping contoh.

2. Uji Chi-Square digunakan untuk menganalisis hubungan antara penerimaan ibu dengan pekerjaan contoh dan suami.

3. Uji Regresi Linier dilakukan untuk menganalisis pengaruh karakteristik contoh dan keluarga; penerimaan; tingkat stres terhadap strategi koping contoh.

\section{HASIL DAN PEMBAHASAN}

\section{Karakteristik Contoh dan Keluarga}

Hasil analisis terhadap karakteristik contoh (ibu) menunjukkan bahwa sebagian besar contoh termasuk kelompok usia dewasa muda $(68,75 \%)$, dan hanya sedikit yang tergolong dewasa lanjut (2,5\%). Tingkat pendidikan contoh menyebar dari kategori tidak sekolah hingga tamat SMA; dan mengumpul di kategori tidak tamat SD $(41,25 \%)$ dan tamat SD $(37,5 \%)$. Sebagian besar contoh tidak bekerja $(81,25 \%)$; hanya $18,75 \%$ yang bekerja sebagai buruh, pedagang, petani, dan PNS.

Hasil analisis terhadap karakteristik keluarga menunjukkan bahwa suami contoh umumnya menyebar pada kategori usia dewasa muda $(57,5 \%)$ dan dewasa madya $(38,75 \%)$. Sama seperti halnya contoh, tingkat pendidikan suami contoh juga menyebar dari kategori tidak sekolah hingga tamat SMA; serta mengumpul di kategori tidak tamat SD $(27,5 \%)$ dan tamat SD $(48,75 \%)$. Namun demikian, tingkat pendidikan suami cenderung lebih tinggi dari contoh. Kebalikan dengan contoh, sebagian besar suami contoh bekerja $(96,25 \%)$ sebagai buruh, pedagang, petani, tukang ojeg, karyawan pabrik, dan pensiunan. Sebanyak $3,75 \%$ suami contoh tidak bekerja. Pendapatan/kapita/bulan keluarga contoh dapat dikelompokkan menjadi tiga, yaitu kurang dari Rp 183.067,00 atau di bawah garis kemiskinan Kabupaten Bogor tahun 2006 (sebanyak 57,5\% keluarga), dan di atas garis kemiskinan, yaitu antara Rp 183.067,00 hingga Rp 366.135,00 (31,25\% keluarga), dan lebih dari Rp 366.135,00 (11,25\% keluarga). Adapun besar keluarga contoh menyebar dari keluarga kecil (anggota keluarga 4 atau kurang), sedang (anggota 57 orang), dan besar (anggota lebih dari 7 orang) berturut-turut $43,73 \%, 35 \%$, dan $21,25 \%$.

\section{Penerimaan Contoh}

Dari semua contoh penerima program konversi minyak tanah ke LPG, ternyata tidak semuanya menggunakan LPG yang diberikan oleh pemerintah pada saat penelitian dilakukan, yaitu sebanyak $8,75 \%$ dengan berbagai alasan (dijual untuk memenuhi kebutuhan hidupnya, diberikan kepada anak). Secara umum, sebanyak 42,5\% contoh memiliki tingkat penerimaan tinggi terhadap program konversi minyak tanah ke LPG, sedangkan penerimaan $56,25 \%$ contoh termasuk kategori sedang, dan sisanya $(1,25 \%)$ rendah. Berdasarkan penerimaan dimensi kognitif, $38,75 \%$ contoh memiliki penerimaan tinggi, $60 \%$ sedang dan $1,25 \%$ rendah. Berdasarkan penerimaan dimensi afektif, $50 \%$ contoh memiliki penerimaan tinggi, 48,75\% cukup, dan 1,25\% kurang.

\section{Tingkat Stres Contoh}

Dari semua contoh penerima program konversi minyak tanah ke LPG, sebanyak $37,5 \%$ contoh mengalami gejala stres meskipun pada tingkat rendah. Sementara itu, sisanya tidak mengalami stres.

Gejala stres fisik yang paling banyak dialami oleh contoh adalah pusing/sakit 
kepala, perubahan berat badan, dan pegalpegal pada leher; sedangkan gejala stres emosional yang paling banyak dialami contoh adalah merasa tidak tenang dan malas bekerja.

\section{Strategi Koping Contoh}

Sebagian besar contoh penerima program konversi minyak tanah ke LPG $(72,50 \%)$ memiliki upaya strategi koping tinggi dalam menghadapi perubahan energi dari minyak tanah ke LPG. Sementara itu, sisanya memiliki strategi koping cukup $(26,25 \%)$ dan rendah $(1,25 \%)$.

Jenis upaya strategi koping yang digunakan oleh contoh kebanyakan adalah jenis dominan Problem Focused Coping (PFC) (56,25\%), sedangkan selebihnya adalah dominan Emotion Focused Coping (EFC) $(26,25 \%)$ dan kombinasi PFC dengan EFC $(17,5 \%)$.

Bila dikaji lebih lanjut, maka strategi koping contoh dapat dikelompokkan menjadi empat tipe, yaitu Tipe A (PFC rendah, EFC rendah), Tipe $B$ (PFC tinggi, EFC rendah), Tipe C (PFC rendah, EFC tinggi), Tipe D (PFC tinggi, EFC tinggi). Hasil penelitian menunjukkan bahwa sebagian besar contoh $(68,75 \%)$ menerapkan strategi koping tipe D. $\mathrm{Hal}$ ini menunjukkan bahwa contoh kreatif menggunakan banyak upaya - baik PFC maupun EFC - untuk mengatasi stres, yaitu secara aktif mengatasi stres, melakukan perencanaan, penekanan pada kegiatan lain, pengendalian perilaku, dan mencari dukungan fisik/bantuan dari lingkungannya dalam upaya mengatasi stres (PFC). Selain itu, contoh juga berupaya untuk berpaling pada agama, pendewasaan diri, mencari dukungan emosional dari lingkungannya, mengekspresikan emosinya berupa penerimaan atau penolakannya (EFC). Sementara itu sebanyak $18,75 \%$ contoh melakukan upaya stategi koping Tipe $\mathrm{C}$, sedangkan sisanya melakukan upaya Tipe A dan Tipe B.

\section{Hubungan antara Karakteristik Contoh dengan Penerimaan Contoh}

Hasil uji statistik menunjukkan bahwa umur (kolerasi Pearson), pendidikan (kolerasi Pearson), dan jenis pekerjaan contoh (ChiSquare) tidak berhubungan dengan penerimaan contoh terhadap program konversi minyak tanah ke LPG. Diduga, tingkat pendidikan contoh yang umumnya rendah (SD dan tidak tamat SD), serta status pekerjaan contoh yang umumnya tidak bekerja menyebabkan variasi pengetahuan dan pengalaman contoh tentang LPG relatif sama.

Hubungan antara Karakteristik Keluarga dengan Penerimaan Contoh

Hasil uji statistik menunjukkan tidak ada hubungan nyata antara umur (kolerasi Pearson), pendidikan (kolerasi Pearson), jenis pekerjaan suami (Chi-Square) dengan penerimaan contoh. Hal ini diduga pendidikan suami yang umumnya rendah (SD dan tidak tamat SD) serta pekerjaan suami contoh yang kurang beragam membuat kurang beragamnya pengetahuan dan pengalaman suami contoh tentang LPG.

Hasil uji Korelasi Pearson menunjukkan adanya hubungan nyata negatif antara pendapatan/kapita/bulan keluarga dengan penerimaan contoh ( $r=-0,301 ; p=0,007)$. Semakin rendah pendapatan/kapita/bulan, maka semakin tinggi penerimaan contoh. Makin rendah pendapatan diduga makin membuat contoh merasa memerlukan konversi minyak tanah ke LPG mengingat harga minyak tanah yang melambung tinggi dan memberatkan, sementara LPG dirasa lebih hemat dan praktis.

Hasil uji korelasi Pearson menunjukkan adanya hubungan nyata negatif antara besar keluarga dengan tingkat penerimaan contoh $(r=-0,230 ; p=0,030)$. Semakin kecil keluarga, semakin tinggi penerimaannya terhadap program konversi ini. Diduga dengan semakin sedikitnya jumlah anggota keluarga, semakin mudah menerima inovasi baru (program konversi), demikian pula sebaliknya.

\section{Hubungan antara Penerimaan dengan Tingkat Stres Contoh}

Uji korelasi Pearson menunjukkan bahwa tidak ada hubungan nyata antara tingkat penerimaan contoh dengan tingkat stres contoh. Hal ini diduga karena tingkat penerimaan contoh umumnya pada kategori tinggi (42,5\%) dan sedang (56,25\%), sementara tingkat stres contoh umumnya pada kategori tidak stres (62,5\%). Dengan kata lain, program konversi ini tidak membuat kebanyakan contoh menjadi stres meskipun contoh tidak sepenuhnya menerima program tersebut.

\section{Hubungan antara Tingkat Stres dengan Strategi koping Contoh}

Hasil uji Korelasi Pearson tidak menunjukkan adanya hubungan nyata antara tingkat stres contoh dengan tingkat strategi koping. Hal ini diduga karena sebagian besar 
contoh penerima program konversi minyak tanah ke LPG memiliki upaya strategi koping tinggi $(72,5 \%)$ dan cukup $(26,25 \%)$ dalam menghadapi perubahan energi dari minyak tanah ke LPG, dan yang memiliki strategi koping rendah hanya $1,25 \%$. Di samping itu, sebagian besar contoh $(68,75 \%)$ menerapkan strategi koping tipe $D$ yang menunjukkan bahwa contoh secara kreatif menggunakan banyak upaya untuk mengatasi stres. Dengan demikian, umumnya contoh - yang stres maupun tidak stres - sama-sama berupaya beradaptasi dengan kondisi yang baru (program konversi) dengan melakukan berbagai strategi koping serta berusaha menerimanya meskipun tidak semua contoh menerima sepenuhnya (memiliki tingkat penerimaan tinggi).

\section{Faktor-faktor yang Berpengaruh terhadap Strategi Koping}

Hasil uji regresi menunjukkan bahwa umur contoh, lama pendidikan suami contoh, pekerjaan suami contoh, pendapatan/kapita/ bulan keluarga, besar keluarga, penerimaan contoh, dan tingkat stres contoh memiliki pengaruh sebesar $18,8 \%$ terhadap strategi koping contoh. Sementara itu, selebihnya dijelaskan oleh variabel-variabel lain di luar model tersebut.

Dari model regresi linier berganda diketahui bahwa hanya variabel penerimaan contoh $(p=0,002)$ dan pendapatan/kapita/ bulan keluarga $(p=0,003)$ yang memiliki pengaruh nyata terhadap strategi koping contoh. Di antara kedua variabel tersebut, variabel penerimaan contoh memiliki pengaruh yang lebih besar terhadap strategi koping yang dilakukan contoh karena memiliki nilai beta terstandardisasi tertinggi, yakni sebesar 0,380.

Variabel penerimaan contoh memiliki nilai koefisien B sebesar 0,101, artinya setiap terjadi peningkatan satu skor penerimaan contoh, maka akan meningkatkan jumlah strategi koping contoh yang dilakukan sebanyak 0,101 cara. Hal ini menunjukkan bahwa semakin bertambahnya tingkat penerimaan, maka akan semakin baik strategi koping yang dilakukan untuk menghadapi permasalahan yang dialaminya.

Variabel pendapatan/kapita/bulan keluarga memiliki nilai koefisien $B$ sebesar $5,02 \times 10^{-06}$. Artinya, setiap kenaikan pendapatan/kapita/bulan keluarga sebanyak Rp 1,00, maka akan meningkatkan jumlah strategi koping yang dilakukan sebanyak $5,02 \times 10^{-06}$ cara. Hal ini menunjukkan bahwa semakin bertambah pendapatan/kapita/bulan keluarga, maka semakin baik strategi koping yang dilakukan untuk menghadapi permasalahan yang dialaminya.

Keluarga dengan pendapatan yang lebih tinggi umumnya lebih sering melakukan strategi koping yang lebih adaptif dibandingkan strategi koping defensif yang kaku dan tidak rasional (Hann 1977 dalam Furi 2006).

\section{KESIMPULAN DAN SARAN}

\section{Kesimpulan}

Karakteristik contoh menunjukkan bahwa sebagian besar termasuk kelompok usia dewasa muda $(68,75 \%)$, dengan tingkat pendidikan mengumpul pada kategori tidak tamat SD $(41,25 \%)$ dan tamat SD $(37,5 \%)$, dan sebagian besar tidak bekerja $(81,25 \%)$.

Karakteristik keluarga menunjukkan bahwa suami contoh menyebar pada usia dewasa muda $(57,5 \%)$ dan dewasa madya $(38,75 \%)$, dengan tingkat pendidikan mengumpul pada kategori tidak tamat SD $(27,5 \%)$ dan tamat SD $(48,75 \%)$, dan sebagian besar bekerja $(96,25 \%)$. Pendapatan/kapita/bulan keluarga contoh menyebar dalam tiga kelompok, yaitu kurang dari Rp 183.067,00 atau di bawah garis kemiskinan Kabupaten Bogor tahun 2006 (57,5\% keluarga), dan di atas garis kemiskinan, yaitu antara Rp 183.067,00 hingga Rp 366.135,00 (31,25\% keluarga), dan lebih dari $\mathrm{Rp} \quad 366.135,00 \quad(11,25 \%$ keluarga). Besar keluarga contoh menyebar dari keluarga kecil (anggota keluarga 4 atau kurang), sedang (anggota 5-7 orang), dan besar (anggota lebih dari 7 orang) berturutturut $43,73 \%$, 35\%, dan $21,25 \%$.

Tidak semua contoh (peserta program konversi) menggunakan LPG, yaitu sebanyak $8,75 \%$ dengan berbagai alasan. Tingkat penerimaan contoh terhadap program konversi umumnya mencakup kategori tinggi $(42,5 \%)$ dan sedang $(56,25 \%)$. Berdasarkan penerimaan dimensi kognitif, $38,75 \%$ contoh memiliki penerimaan tinggi, $60 \%$ sedang dan $1,25 \%$ rendah. Berdasarkan penerimaan dimensi afektif, $50 \%$ contoh memiliki penerimaan tinggi; $48,75 \%$ cukup; dan $1,25 \%$ kurang.

Sebanyak $37,5 \%$ contoh mengalami gejala stres tingkat rendah, dan sisanya tidak mengalami stres. Sebagian besar contoh $(72,5 \%)$ memiliki upaya strategi koping tinggi dalam menghadapi perubahan energi dari minyak tanah ke LPG, sisanya cukup $(26,25 \%)$ dan rendah $(1,25 \%)$. Jenis upaya strategi koping yang digunakan oleh contoh 
kebanyakan adalah jenis dominan Problem Focused Coping (PFC) (56,25\%), selebihnya adalah dominan Emotion Focused Coping (EFC) $(26,25 \%)$, dan kombinasi PFC dengan EFC (17,5\%). Sebagian besar contoh $(68,75 \%)$ menerapkan strategi koping tipe D (PFC tinggi, EFC tinggi) untuk mengatasi stres.

Umur, pendidikan, dan jenis pekerjaan contoh tidak berhubungan dengan penerimaan contoh terhadap program konversi minyak tanah ke LPG. Tidak ada hubungan antara umur, pendidikan, jenis pekerjaan suami dengan penerimaan contoh. Ada hubungan nyata negatif antara pendapatan/kapita/bulan keluarga dengan penerimaan contoh. Semakin tinggi pendapatan/kapita/bulan, maka semakin rendah penerimaan contoh. Ada hubungan nyata negatif antara besar keluarga dengan tingkat penerimaan contoh. Semakin kecil keluarga, semakin tinggi penerimaannya terhadap program konversi.

Tidak ada hubungan nyata antara tingkat penerimaan contoh dengan tingkat stres contoh. Tidak ada hubungan nyata antara tingkat stres dengan tingkat strategi koping contoh.

Umur contoh, lama pendidikan suami contoh, pekerjaan suami contoh, pendapatan/kapita/bulan keluarga, besar keluarga, penerimaan contoh, dan tingkat stres contoh memiliki pengaruh sebesar $18,8 \%$ terhadap strategi koping contoh. Sementara itu, selebihnya dijelaskan oleh variabel-variabel lain di luar model tersebut. Hanya variabel penerimaan contoh dan pendapatan/kapita/bulan keluarga yang memiliki pengaruh nyata terhadap strategi koping contoh, di mana variabel penerimaan contoh memiliki pengaruh yang lebih besar terhadap strategi koping yang dilakukan contoh.

\section{Saran}

Hasil penelitian menunjukkan bahwa keluarga berpendapatan lebih rendah dan keluarga lebih kecil ternyata lebih menerima program konversi. Oleh karena itu, disarankan kepada pemerintah untuk lebih mengutamakan program konversi minyak tanah ke LPG kepada keluarga dengan pendapatan rendah dengan keluarga kecil.

Hasil penelitian menunjukkan bahwa penerimaan contoh merupakan faktor yang paling berpengaruh terhadap strategi koping. Oleh karena itu, untuk meningkatkan kemampuan koping terhadap stres akibat adanya program konversi disarankan kepada pemerintah untuk meningkatkan penerimaan masyarakat, terutama ibu, terhadap program konversi minyak tanah ke LPG. Hal ini dapat dilakukan melalui sosialisasi (penyuluhan) yang lebih intensif kepada kelompokkelompok kemasyarakatan, seperti pengajian, PKK, Dasa Wisma, dan lain-lain di desadesa, terutama pada keluarga-keluarga yang berpendapatan rendah dengan keluarga kecil.

\section{DAFTAR PUSTAKA}

Adams ME. 1988. Agricultural Extention in Developing Countries. Firstman Edition. Longman Singapore Publisher Pte Ltd: Singapore.

Anonim. 2008. "Konversi Minyak Tanah ke LPG". http://ariodesign.blogspot.com/2008/11/ html. 6 Mei 2008.

Blechman BM, Edward MG, Robert W. 1975. Setting National Priorities: The 1976 Budget. WashingtonDC: The Brookings Institution.

Engel JF, Blackwell RD, Miniard PW. 1995. Consumer Behaviour. $8^{\text {th }}$ ed. Forth Worth, Texas: The Dryden Press.

Furi AE. 2006. Persepsi, Tingkat Stres, dan Strategi Koping Ibu pada Keluarga Miskin Penerima Bantuan Langsung Tunai (BLT) terhadap Kenaikan Harga Bahan Bakar Minyak (BBM) [Skripsi]. Bogor: Jurusan Gizi Masyarakat dan Sumberdaya Keluarga, Fakultas Pertanian, Institut Pertanian Bogor.

Goldsmith AB. 1996. Resource Management for Individuals and Families. USA: West Publishing Company.

Gross IH, Crandal EW. 1980. Management for Modern Families. New York: Appletor-Century-Crofts Inc.

Gunarsa SD, Gunarsa YS. 2004. Psikologi Praktis: Anak, Remaja, dan Keluarga. Jakarta: PT BPK Gunung Mulia.

Hasyim I. 2005. Siklus Krisis di Sekitar Energi. Jakarta: Proklamasi Publishing House.

Hayslip B, Panek PE. 1989. Adult Development and Aging. United States of America: Harper \& Row Publisher.

Hurlock. 1991. Perkembangan Anak. Edisi ke-6. Jakarta: Erlangga.

Kahn AJ. 1969. Theory and Practice in Social Planning. New York: Russell Sage Foundation.

Kotler P. 2000. Marketing Management. 
Millenium Editor. New Jersey: Prentice Hall.

McCubbin HI, Thompson Al. 1987. Family Assessment Inventories. United States of America: The University of Winconsin. Melson GF. 1980. Family and Environment, an Ecosystem Perspective. United States of America: Burgess Publishing Company.

Mowen JC, Minor M. 1999. Consumer Behaviour. $5^{\text {th }}$ ed. New Jersey: Prentice Hall.

Nurmayanti, N. 2009. Analisis Tingkat Kesejahteraan, Sikap, Perilaku, dan Tingkat Kepuasan Keluarga Sasaran Program Konversi Minyak Tanah ke LPG di Kota Bekasi. [Skripsi]. Bogor: Fakultas Ekologi Manusia, Institut Pertanian Bogor.

Papalia DE, Olds SW. 1981. Human Development. Edisi ke-2. USA: Mc Graw Hill, Inc.

* Korespondensi :

Email : mellylatifah@yahoo.com 